\title{
L-AP4 Inhibits Calcium Currents and Synaptic Transmission via a G-Protein-coupled Glutamate Receptor
}

\author{
Paul Q. Trombley ${ }^{1, a}$ and Gary L. Westbrook ${ }^{2}$ \\ 1Department of Biology and Institute of Neuroscience, University of Oregon, Eugene, Oregon 97403 and ${ }^{2}$ Vollum Institute \\ and Department of Neurology, Oregon Health Sciences University, Portland, Oregon 97201
}

\begin{abstract}
The AP4 (2-amino-4-phosphonobutyrate) receptor is a presynaptic glutamate receptor that inhibits transmitter release via an unknown mechanism. We examined the action of L-AP4 on voltage-dependent calcium currents and excitatory synaptic transmission on cultured olfactory bulb neurons using whole-cell voltage-clamp methods. In neurons dialyzed with GTP, L-AP4 inhibited high-threshold calcium currents evoked in barium solutions. The inhibition was irreversible in the presence of GTP- $\gamma-S$ and blocked by removing intracellular $\mathbf{M g}^{2+}$ or by preincubation with pertussis toxin (PTX), consistent with the involvement of a PTX-sensitive G-protein. Dialysis with staurosporine or buffering of intracellular calcium to $\mathrm{pCa}<\mathbf{8}$ did not block the action of L-AP4, suggesting that protein phosphorylation or release of intracellular calcium stores was not involved in calcium current inhibition under these experimental conditions. PTX also blocked the L-AP4-induced inhibition of monosynaptic EPSPs evoked by intracellular stimulation of cultured mitral cells. These results suggest that the presynaptic AP4 receptor is a G-protein-coupled glutamate receptor, and that inhibition of calcium influx by a membrane-delimited action of a G-protein may account for L-AP4-induced presynaptic inhibition.
\end{abstract}

Many excitatory synaptic pathways in the mammalian CNS use L-glutamate as a transmitter (Cotman et al., 1987; Mayer and Westbrook, 1987). Glutamate activates ion channels in the postsynaptic membrane linked to NMDA and AMPA ( $\alpha$-amino-3hydroxy-5-mcthyl-4-isoxazoleproprionic acid) receptors. The contributions of these receptor/channels to the excitatory postsynaptic current can be distinguished on the basis of time course and single-channel properties (e.g., Forsythe and Westbrook, 1988; Lester et al., 1990). In addition to ligand-gated ion channels, two other glutamate receptors have been described, the metabotropic receptor and the $\mathrm{L}$-2-amino-4-phosphonobutyrate (L-AP4) receptor (e.g., see Collingridge and Lester, 1989). The metabotropic receptor, first identified in mRNA-injected oocytes, couples to a GTP-binding $(G)$-protein and stimulates

\footnotetext{
Received Oct. 11, 1991; revised Dec. 19, 1991; accepted Dec. 30, 1991.

This work was supported by a predoctoral training grant from the University of Oregon to P.Q.T. and grants from the National Institutes of Health (NS26494) and the Klingenstein Fund for the Neurosciences. We thank Drs. J. Williams and C. Jahr for reading earlier versions of the manuscript.

Correspondence should be addressed to Gary L. Westbrook, Vollum Institute, L474, 3181 SW Sam Jackson Park Road, Oregon Health Sciences University, Portland, OR 97201.

a Present address: Section of Neurobiology, Yale University School of Medicine, 333 Cedar Street, New Haven, CT 06510.

Copyright (c) 1992 Society for Neuroscience $0270-6474 / 92 / 122043-08 \$ 05.00 / 0$
}

phosphatidylinositol 4,5-bisphosphate hydrolysis with subsequent generation of the second messengers diacylglycerol and 1,4,5-inositol trisphosphate (IP ${ }_{3}$; Sugiyama et al., 1987; Sladeczek et al., 1988). The recent cloning of the metabotropic receptor revealed a primary sequence consistent with a G-proteincoupled receptor (Houamed et al., 1991; Masu et al., 1991).

The coupling mechanism for the L-AP4 receptor is not defined. Except in the retina (Miller and Slaughter, 1986; Nawy and Jahr, 1990), the L-AP4 receptor appears to be located primarily on presynaptic nerve terminals, suggesting an action as an autoreceptor controlling glutamate release. L-AP4 inhibits glutamate-mediated EPSPs in the hippocampus, olfactory cortex, and spinal cord (Davies and Watkins, 1982; Harris and Cotman, 1983; Anson and Collins, 1987), as well as EPSPs in cultures of hippocampal neurons (Forsythe and Clements, 1990) and olfactory bulb (Trombley and Westbrook, 1990). There are, however, marked differences in the sensitivity of synaptic pathways to L-AP4. The lateral perforant path input to the hippocampal dentate gyrus and the lateral olfactory tract, the major output pathway of the olfactory bulb, are among the most sensitive (for review, see Mayer and Westhrook, 1987).

G-proteins regulate a large array of cellular processes including both regulation of ion channels and modulation of transmitter release by presynaptic receptors (Dunlap et al., 1987; Gilman, 1987; Ross, 1989). Several presynaptic receptors including $\mathrm{GABA}_{\mathrm{B}}, \mathrm{A} 1$ adenosine, and $\alpha_{2}$ adrenergic receptors may inhibit synaptic transmission by $\mathrm{G}$-protein regulation of calcium channels (Holz et al., 1989; Lipscombe et al., 1989; Scholz and Miller, 1991). This can occur via diffusible second messengers or membrane-delimited actions of G-proteins (Brown and Birnbaumer, 1988). To determine the coupling mechanism of AP4 receptors, we examined voltage-dependent calcium currents and EPSPs in mitral/tufted cells of the olfactory bulb in short-term culture. L-AP4 inhibited high-threshold calcium currents via a pertussis toxin (PTX)-sensitive G-protein. As L-AP4 does not stimulate production of $\mathrm{IP}_{3}$ via activation of the metabotropic receptor (Sladeczek et al., 1988; Sugiyama et al., 1989), our results are consistent with a distinct G-protein-coupled glutamate receptor that can act directly (i.e., in a membrane-delimited manner) on high-threshold calcium channels. L-AP4-mediated inhibition of monosynaptic EPSPs was also PTX sensitive, suggesting that AP4 receptors on nerve terminals are coupled to a similar G-protein.

\section{Materials and Methods}

Cell culture. Olfactory bulbs were dissected from 5-7-d-old rat pups that were anesthetized with halothane and killed by decapitation. Neurons were incubated in activated papain, dissociated by gentle tritura- 


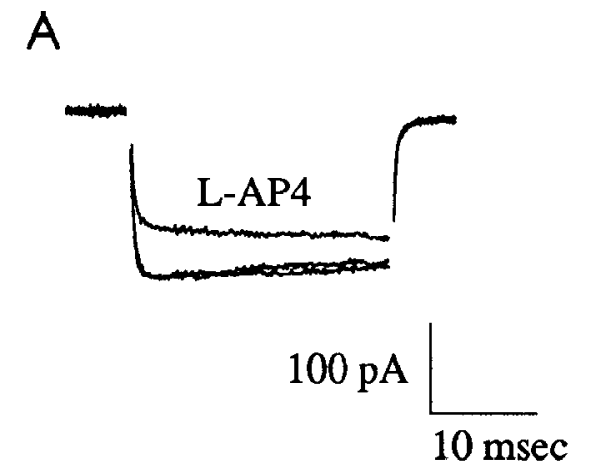

Figure 1. L-AP4 reversibly blocks high-threshold calcium currents in olfactory bulb neurons. $A$, Under voltage clamp, a $25 \mathrm{msec}$ voltage step to $0 \mathrm{mV}$ from a holding potential of $-60 \mathrm{mV}$ evoked a sustained inward barium current through high-threshold calcium channels. $B, \mathrm{~L}-\mathrm{AP} 4(30 \mu \mathrm{M})$ reversibly reduced the current by $27 \%$ at $2 \mathrm{~min}$ and by $25 \%$ at $17 \mathrm{~min}$ after the beginning of whole-cell recording. $C, I-V$ relationship for the effects of $30 \mu \mathrm{M} \mathrm{L}-\mathrm{AP} 4$ on the barium current. Bath contained no added glycine and $100 \mu \mathrm{M}$ AP5.

tion, and plated on confluent layers of olfactory bulb astrocytes as previously described (Trombley and Westbrook, 1990). Whole-cell recordings were made after 6-48 hr in culture. Excitatory synaptic transmission between olfactory bulb neurons was studied after 7-10 d from cultured neurons obtained from newborn rats.

Electrophysiology. Voltage- and current-clamp recordings were performed at room temperature using a discontinuous voltage-clamp amplifier (Axoclamp 2A, Axon Instruments). During voltage clamp, the membrane voltage was continuously monitored to ensure adequate voltage control; switching frequencies were $10-15 \mathrm{kHz}$. The recording chamber was perfused at $0.5-2.0 \mathrm{ml} / \mathrm{min}$ with a solution containing (in $\mathrm{mM}$ ) $\mathrm{NaCl}, 145 ; \mathrm{KCl}, 2.5 ; \mathrm{CaCl}_{2}, 2.0 ; \mathrm{HEPES}, 10$; glucose, $10 ; \mathrm{MgCl}_{2}, 1.0$; and no added glycine. The $\mathrm{pH}$ was adjusted to 7.3 with $\mathrm{NaOH}$ and the osmolarity to $325 \mathrm{mOsm}$ with sucrose. During recording, neurons were locally perfused via an array of $400 \mu \mathrm{m}$ i.d. glass barrels fed by gravity from drug reservoirs. Neurons were always bathed from one barrel containing control solution except during application of drugs. Calcium currents were evoked in solutions containing tetrodotoxin $(0.3 \mu \mathrm{M})$ and $10 \mathrm{~mm}$ barium substituted for calcium. In experiments with quisqualate, glutamatc, and ibotenatc, $100 \mu \mathrm{M}$ DL-aminophosphonopentanoic acid (DL-AP5) and/or $100 \mu \mathrm{M}$ 6-cyano-7-dinitroquinoxaline-2,3-dione (CNQX) was added to prevent activation of agonist-gated ion channels. During recording of EPSPs, DL-AP5 $(100 \mu \mathrm{M})$ and picrotoxin $(20 \mu \mathrm{M})$ were added to block NMDA and GABA receptor-mediated synaptic potentials. Patch electrodes (4-6 MR) were pulled from borosilicate glass, fire polished, and filled with solution containing (in mм) $\mathrm{KMeSO}_{4}$ or CsCl, 140; $\mathrm{MgCl}_{2}$, 5; HEPES, 10; Na-ATP, 5; Na-GTP, 0.5; and EGTA, 1.1 or $11 ; \mathrm{pH} 7,2,310$ mOsm. To obtain low intracellular $\mathbf{M g}^{2+}$ in some experiments, $\mathrm{Mg}^{2+}$ was omitted from the patch solution, and EGTA was replaced by $11 \mathrm{~mm}$ EDTA. Most drugs were dissolved in water and diluted in the recording solution before use. CNQX stocks were dissolved in dimethylsulfoxide (final concentration, $<0.1 \%$ ), and nifedipine, in absolute ethanol (final concentration, $<0.01 \%$ ). Most chemicals were obtained from Sigma. L-AP4 and excitatory amino acids were obtained from Cambridge Research Biochemicals or Tocris.

Voltage and current protocols were generated using pCLAMP software (version 5.5, Axon Instruments); EPSPs and membrane currents were digitized and stored for later analysis on an IBM-AT. Barium currents were evoked by $25 \mathrm{msec}$ voltage jumps from $-60 \mathrm{mV}$ at $30 \mathrm{sec}$ intervals.
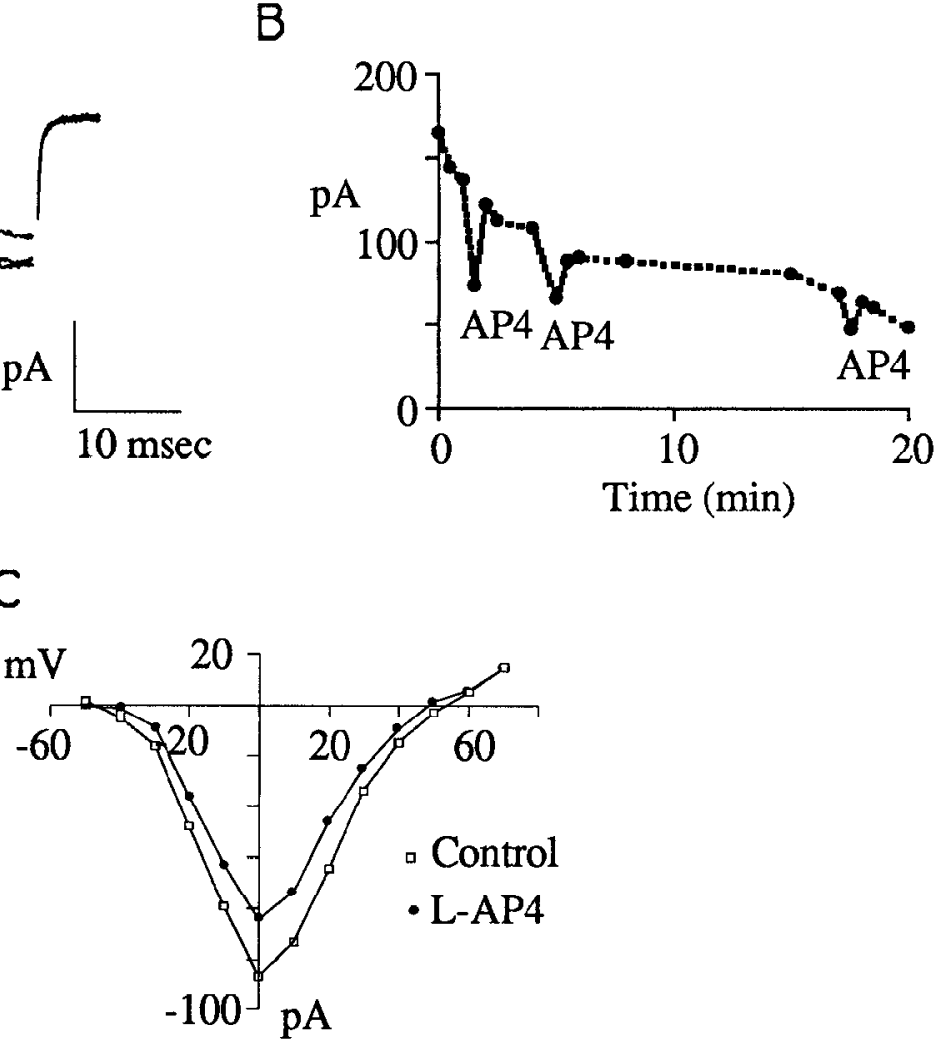

Current records wcrc filtered at $1-3 \mathrm{kHz}$ (eight-pole Bessel filter). Membrane currents and EPSPs were collected as averages of three to five trials; measurements were made at the peak. To determine the inhibition by L-AP4 or norepinephrine (NE), the control barium current amplitude was taken as the average of peak current values immediately before and after drug application in order to correct for current rundown. Peak current amplitudes and inhibition of current by L-AP4 or NE were measured as the average of a $2 \mathrm{msec}$ data epoch beginning $10 \mathrm{msec}$ after the onset of the voltage jump. Leak and capacitative currents were subtracted using a $P / 4$ procedure; the initial $400 \mu \mathrm{sec}$ after a voltage jump had uncanceled capacitative transients and was blanked. Results are reported as mean $\pm \mathrm{SD}$.

\section{Results}

\section{L-AP4 reversibly blocks the high-threshold calcium current}

High-threshold calcium currents were evoked in olfactory bulb neurons dissociated from 5-7-d-old rat pups. Whole-cell recordings were made after $12-48 \mathrm{hr}$ in culture; under these conditions adequate space clamp was possible before extensive neuritic outgrowth had occurred. We restricted our analysis to large neurons that are putative mitral/tufted cells based on their physiological and immunohistochemical criteria (Trombley and Westbrook, 1990). Calcium currents were isolated by blocking voltage-dependent sodium channels with TTX; potassium channels were blocked using cesium in the patch pipette. In most experiments, barium (10 $\mathrm{mm}$ ) was substituted for calcium as the charge carrier. As shown in Figure $1 A$, a $25 \mathrm{msec}$ depolarizing voltage step to $0 \mathrm{mV}$ from a holding potential of $-60 \mathrm{mV}$ evoked a sustained inward current. The barium current was completely blocked by $\mathrm{Cd}$ and showed little inactivation even with $150 \mathrm{msec}$ voltage jumps (not shown). The inward current activated near $-40 \mathrm{mV}$ peaked at $0 \mathrm{mV}$ and reversed near +55 $\mathrm{mV}$ (Fig. 1C). Nifedipine (1 $\mu \mathrm{M}$ ) reduced the current by $38 \pm$ $14 \%(n=7)$ from a holding potential of $-80 \mathrm{mV}$, suggesting 
that at least part of the current was due to L-type calcium channels. Although we did not attempt to determine the relative contribution of N- and L-type channels to the high-threshold current, which can vary considerably between neuronal cell types, the incomplete block by high concentrations of nifedipine is similar to that reported in acutely isolated hippocampal or visual cortex neurons (Regan et al., 1991). Transient (T-type) calcium currents were small and rarely observed in these neurons even from a holding potential of $-100 \mathrm{mV}$; however, we used a holding potential of $-60 \mathrm{mV}$ where $\mathrm{T}$-currents are largely inactivated (Fox et al., 1987).

Rapid perfusion with L-AP4 (1-300 $\mu \mathrm{M})$ reversibly inhibited the high-threshold calcium current in more than $80 \%$ of the neurons tested (Fig. $1 A, B$ ). The inhibition of inward barium current was similar for voltage jumps to membrane potentials between -40 and $+40 \mathrm{mV}$, although the effect of L-AP4 on outward current through calcium channels was minimal as shown in voltage jumps to +60 and $+70 \mathrm{mV}$ (Fig. $1 C$ ). L-AP4 had little effect at $1 \mu \mathrm{M}(n=7)$ and was maximal at concentrations near $30 \mu \mathrm{M}$. In the presence of $30 \mu \mathrm{M} \mathrm{L}-\mathrm{AP} 4$, currents were reduced by $23.6 \pm 9.1 \%(n=59)$. Similar concentrations of L-AP4 have been shown to be effective in inhibiting transmitter release from mitral cells in brain slices and in culture (Anson and Collins, 1987; Trombley and Westbrook, 1990). Although L-AP4 also is a weak agonist at NMDA receptors (see Mayer and Westbrook, 1987), NMDA receptors were blocked in these experiments by adding $\mathrm{Mg}^{2+}(1 \mathrm{mM})$ and DL-AP5 (100 $\left.\mu \mathrm{M}\right)$ to glycine-free medium. L-AP4 also had no effect on the resting conductance or on potassium currents evoked by voltage stcps to $+20 \mathrm{mV}$ (data not shown).

In the presence of L-AP4, there was a slow increase in the barium current during a voltage jump (see, e.g., Fig. 1 $A$ ). This relief of inhibition has also been observed for neurotransmitter inhibition of calcium channels in other neurons and has been termed the "reluctant" or "sleepy" channel (see Bean, 1989; Elmslie et al., 1990). The amplitude of the barium current showed slow rundown during intracellular dialysis even with $5 \mathrm{mM} \mathrm{Mg}^{2+}$ / ATP and $0.5 \mathrm{~mm}$ GTP in the pipette. However, as shown in Figure $1 B, \mathrm{~L}-\mathrm{AP} 4$ was still effective in reducing the barium current throughout the recording period, indicating that intracellular dialysis did not occlude the action of L-AP4.

$\mathrm{NE}$ and the selective $\alpha_{2}$ adrenergic receptor agonist UK-14304 also reduced the peak barium current in the isolated olfactory bulb neurons (Fig. 2), as has been observed in other neurons (c.g., Bcan, 1989; Surprenant, 1989). For NE $(30 \mu \mathrm{M})$, the reduction was $29.5 \pm 9.8 \%(n=39)$ for voltage steps to $0 \mathrm{mV}$ from a holding potential of $-60 \mathrm{mV}$. This is similar to that seen with L-AP4. Eight additional neurons showed no response to NE. UK-14304 (500 nM) reduced the barium current by 22.3 $\pm 5.9 \%$ in nine neurons that also responded to $\mathrm{NE}$, consistent with activation of an $\alpha_{2}$ adrenergic receptor (Fig. $2 B$ ).

\section{$P T X$ inhibits the action of $L-A P 4$ on barium currents}

On sympathetic neurons, NE reduces transmitter release that has been attributed to inhibition of high-threshold calcium currents via a G-protein (Lipscombe et al., 1989). This may reflect a general mechanism of action for several presynaptic receptors (e.g., Holz et al., 1989; Scholz and Miller, 1991). In order to determine whether AP4 receptors are coupled to a G-protein, we first tested the effect of removing intracellular $\mathrm{Mg}^{2+}$, which is an absolute rcquircment for activation of $\mathrm{G}$-protcins (Brown and Birnbaumer, 1988). After a $2 \mathrm{hr}$ incubation in a nominally
A
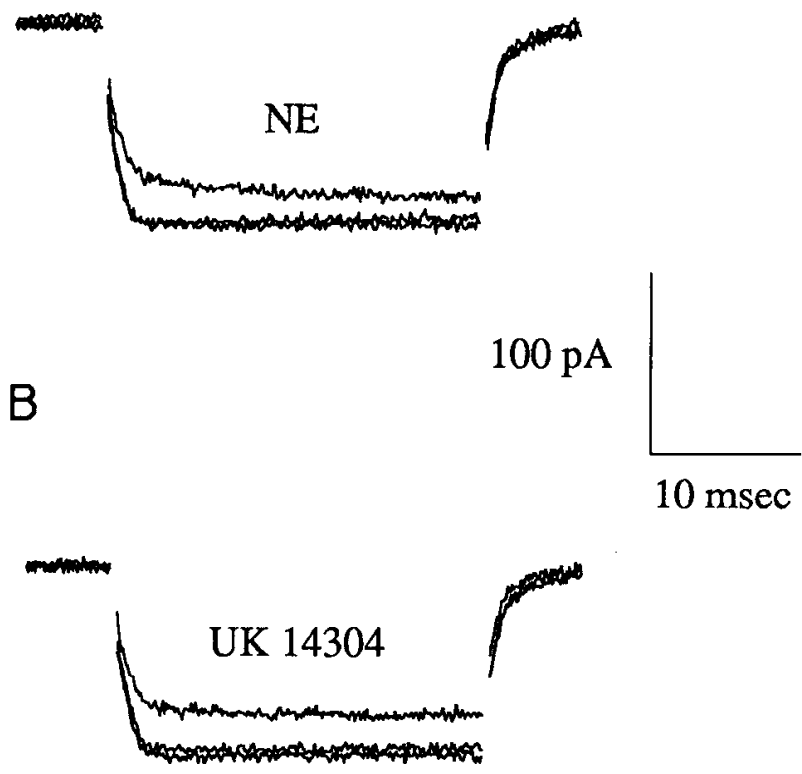

Figure 2. Inhibition of the barium current by NE and the $\alpha_{2}$ adrenergic receptor agonist UK $14304 . A$, NE $(30 \mu \mathrm{M})$ produced a $21 \%$ reduction in the barium current. This was mimicked by $500 \mathrm{~nm}$ UK-14304 $(B)$, which reduced the current by $23 \%$ in the same neuron. The barium current was evoked by a voltage step to $0 \mathrm{mV}$ from a holding potential of $-60 \mathrm{mV}$.

$\mathrm{Mg}^{2+}$-free medium, neurons were dialyzed with a patch electrode containing $11 \mathrm{~mm}$ EDTA and no added $\mathrm{Mg}^{2+}$. As shown in Figure $3 A$, removal of $\mathrm{Mg}^{2+}$ completely blocked the action of L-AP4 (4. $2 \pm 2.4 \%$ reduction; $n=5)$.

More direct evidence for G-protein coupling of AP4 receptors was obtained using the nonhydrolyzable GTP analog GTP- $\gamma$ S. When GTP- $\gamma-S(100 \mu \mathrm{M})$ was substituted for GTP in the patch pipette, L-AP4 reduced the barium current by a similar degree (inset, Fig. $3 B$ ). However, there was essentially no recovery $30 \mathrm{~min}$ following AP4 application, and repeat applications of L-AP4 did not further inhibit the current (not shown). For 14 neurons, the inhibition was $24.4 \pm 7.9 \%$, which was not significantly different from neurons dialyzed with GTP. Subsequent application of NE usually did result in further depression of the barium current (Fig. $3 B$ ), which may suggest that the receptors activated by L-AP4 and NE have access to different pools of G-proteins. In some cells, the rundown of the calcium current appeared to be enhanced with GTP- $\gamma-\mathrm{S}$ in the pipette, consistent with direct activation of G-protein(s) acting on calcium channels (e.g., Toselli et al., 1989). However, the degree of inhibition by L-AP4 was similar compared to GTP-containing pipettes, presumably because L-AP4 was initially applied within 5-10 min of achieving whole-cell recording.

PTX blocks coupling of $\mathrm{G}_{i}$ and $\mathrm{G}_{o}$ proteins to activated receptors by ADP ribosylation (Gilman, 1987). To test the sensitivity of the L-AP4 responses, olfactory bulb neurons were incubated in $250 \mathrm{ng} / \mathrm{ml}$ PTX for $15-36 \mathrm{hr}$. Following PTX treatment, L-AP4 had no measurable effect on the barium current $(+0.9 \pm 7.2 \% ; n=18)$, whereas barium currents in untreated sister cultures were reduced by $21.1 \pm 6.0 \%(n=11)$. 


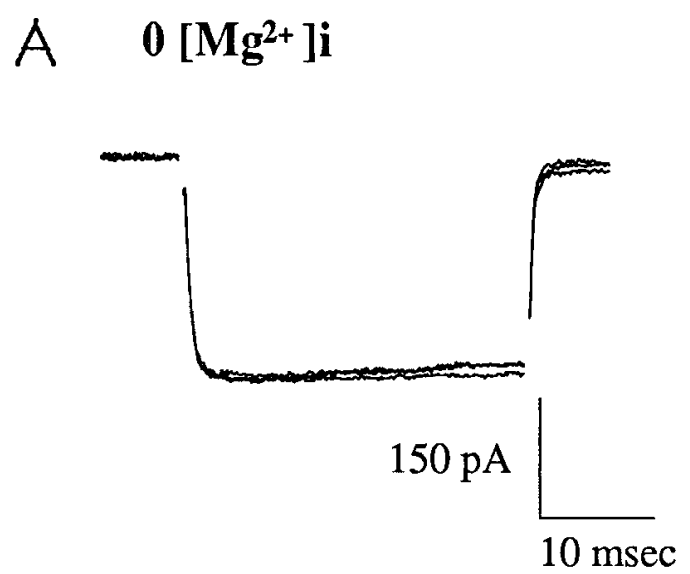

C

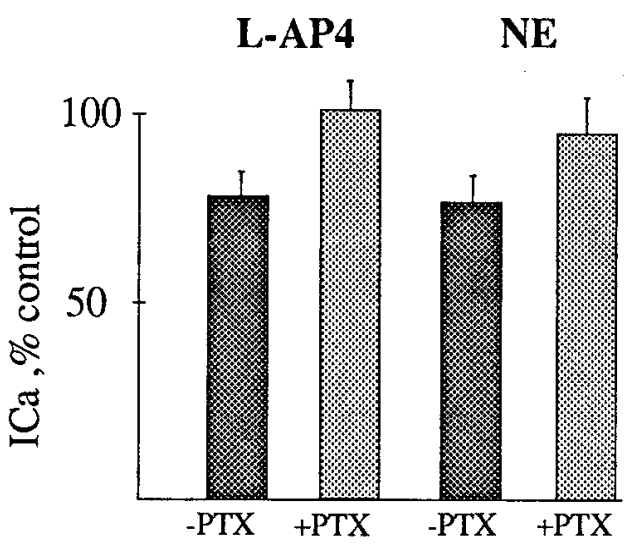

B $\quad$ GTP $\gamma \mathbf{S}$

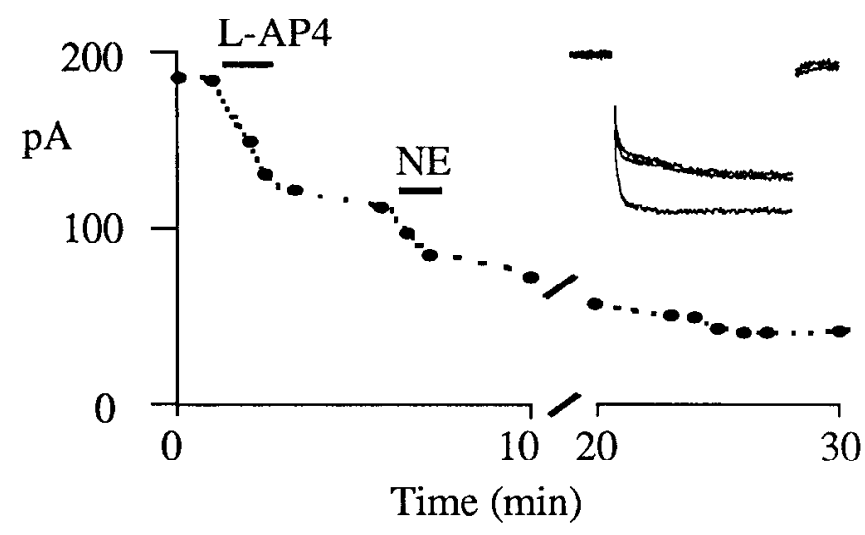

D Staurosporine

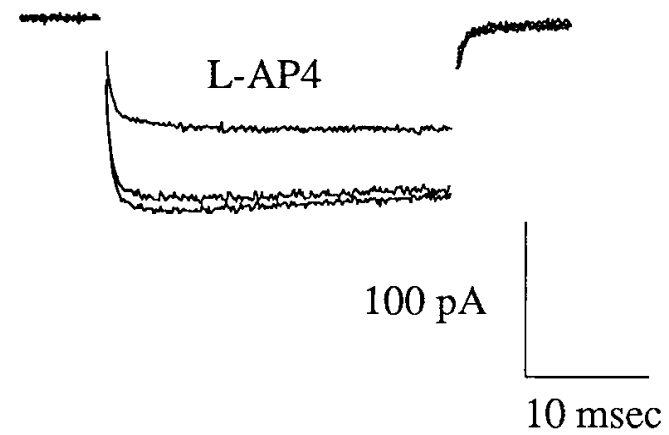

Figure 3. L-AP4 receptor is coupled via a G-protein. $A$, L-AP4 $(30 \mu \mathrm{M})$ had no effect in neurons incubated for $2 \mathrm{hr}$ in a nominally $\mathrm{Mg}^{2+}$-free solution and dialysed with a recording pipette containing $1 \mathrm{mM}$ EDTA and no added $\mathrm{Mg}^{2+}$. $B$, During whole-cell dialysis with GTP- $\gamma-\mathrm{S}$ (100 $\mu \mathrm{M}$ ), L-AP4 and NF. (both at $30 \mu \mathrm{M}$ ) caused irreversible reduction in the barium current. Inset shows barium current during $30 \mathrm{msec}$ voltage step before, during, and after application of L-AP4. C, Inhibition of calcium current by L-AP4 and NE was blocked by pretreatment with PTX (250 ng/ml) for 15-24 hr. Histogram shows inhibition compared to untreated sister cultures. $D$, The nonselective kinase inhibitor staurosporine (1 $\mu \mathrm{M})$ did not prevent inhibition by L-AP4.

This is consistent with the involvement of a PTX-sensitive G-protein in coupling AP4 receptors to calcium channels. Similar results were seen for NE. The barium current in untreated neurons was reduced by $25.2 \pm 4.5 \%(n=10)$, but barium currents were not significantly inhibited by NE in PTX-treated neurons $(5.3 \pm 8.8 \% ; n=18)$. There were no apparent differences between the PTX-treated and sister cultures with respect to other membrane properties such as holding current and the magnitude and voltage dependence of the calcium currents. These results are summarized in Figure $3 C$.

G-protein-coupled receptors can act via diffusible second messengers (Trautwein et al., 1986; Dunlap et al., 1987) or via direct interaction of the $\alpha$-subunit with the ion channel (Brown and Birnbaumer, 1988; Lipscombe et al., 1989; Toselli et al., 1989). We examined whether a protein kinase was required for coupling of AP4 receptors to calcium channels by including staurosporine, a broad-spectrum kinase inhibitor (Rüegg and Burgess, 1989), in the whole-cell pipette. As initial experiments suggested no effect of staurosporine on the barium currents, we used a high concentration and allowed 5-10 min following whole- cell recording for the compound to diffuse completely into the cell. Dialysis for 5-10 min with staurosporine $(1 \mu \mathrm{M})$ did not prevent L- $\Lambda$ P4 inhibition of the barium current (Fig. $3 D$ ). For five neurons, the inhibition was $27.4 \pm 9.4 \%$, which was not significantly different than control (see Fig. 1). This suggests that the action of L-AP4 may not require protein phosphorylation.

Inhibition of barium currents by other excitatory amino acids

In addition to L-AP4, several other glutamate analogs also inhibit transmitter release in the CNS (reviewed in Mayer and Westbrook, 1987), although it is unclear whether more than one glutamate receptor is involved. The best described G-proteincoupled glutamate receptor, the metabotropic receptor, is also linked to a PTX-sensitive G-protein (Sugiyama et al., 1987; Nicoletti et al., 1988), and activation of the metabotropic receptor has also been recently shown to inhibit EPSPs in the hippocampus (Baskys and Malenka, 1991). Glutamate, quisqualate, and ibotenate are effective metabotropic receptor agonists, while L-AP4 is not, as judged by the stimulation of IP ${ }_{3-}^{-}$ mediated activation of the calcium-activated chloride channel 
A

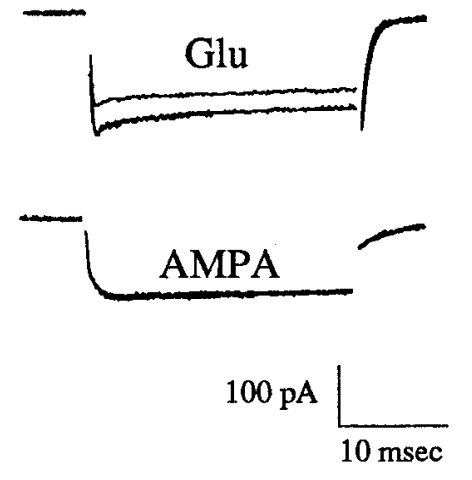

B

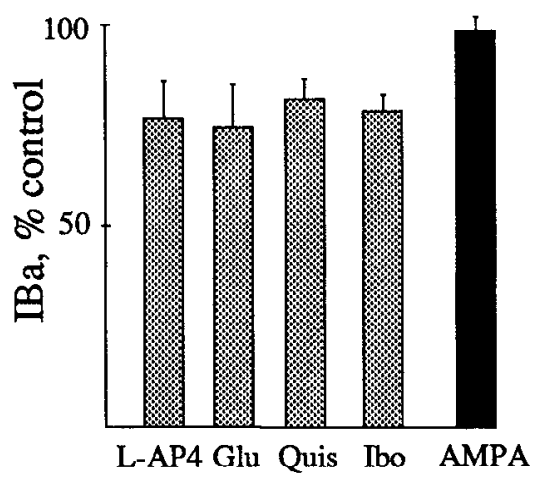

Figure 4. Glutamate analogs that activate the metabotropic glutamate receptor also inhibited the high-threshold calcium current. $A$ and $B$, Glutamate $(100 \mu \mathrm{M})$ reduced the barium current by 25\%; however, AMPA had no effect. Hislogram expresses percent reduction of the control barium current for AMPA $(25 \mu \mathrm{M})$, ibotenate $(100 \mu \mathrm{M} ; I b o)$, quisqualate (1 $\mu \mathrm{M} ;$ Quis), and glutamate (100 $\mu \mathrm{M} ; G l u)$ compared to L-AP4 $(30 \mu \mathrm{M})$. Bath contained $1 \mathrm{~mm} \mathrm{Mg}^{2+}$, no added glycine, $100 \mu \mathrm{M} \mathrm{AP5}$, and $100 \mu \mathrm{M}$ CNQX to block glutamate channel activity in mRNA-injected oocytes (Sugiyama et al., 1989; Houamed et al., 1991; Masu et al., 1991). Likewise, quisqualate and glutamate have been reported to inhibit high-threshold calcium currents in cultured hippocampal neurons (Lester and Jahr, 1990) and cause the release of intracellular calcium (Murphy and Miller, 1988, 1989). However, L-AP4 was ineffective in those experiments.

We tested the effect of metabotropic receptor agonists in barium solutions, and with $10 \mathrm{mM}$ EGTA in the patch pipette, to prevent the effects of $\mathrm{IP}_{3}$-mediated calcium release from intracellular stores. To ensure that glutamate-activated ion channels were blocked, all drug solution contained high concentrations of DL-AP5 $(100 \mu \mathrm{M})$ and CNQX $(100 \mu \mathrm{M})$. This avoided the possible action of NMDA receptor agonists on calcium currents as has been reported on acutely dissociated hippocampal neurons (Chernevskaya et al., 1991). AP5 and CNQX had no apparent direct membrane effects. Under these conditions, L-glutamate reduced the barium current by $25.3 \pm 10.7 \%(n=4)$, whereas AMPA ( $25 \mu \mathrm{M})$, a non-NMDA receptor agonist without activity at metabotropic receptors, had no effect (Fig. 4A). However, both quisqualate $(1 \mu \mathrm{M})$ and ibotenate $(100 \mu \mathrm{M})$, which activate the metabotropic receptor, also reduced the barium current. The inhibition of the peak current was similar for L-AP4 compared to the metabotropic receptor agonists (Fig. $4 B$ ). This suggests either that agonists acting on the metabotropic receptor also activate the AP4 receptor, or that activation of the metabotropic receptor leads to calcium current inhibition via a mechanism independent of $\mathrm{IP}_{3}$-mediated calcium release. This distinction awaits the development of potent and selective antagonists (see Discussion).

\section{L-AP4 block of excitatory synaptic transmission}

The known physiological action of L-AP4 in olfactory pathways is to inhibit transmitter release from mitral cell axons (Anson and Collins, 1987; Trombley and Westbrook, 1990). To determine if a G-protein was involved in presynaptic inhibition, paired whole-cell recordings were used to evoke monosynaptic EPSPs by stimulation of an action potential in the presynaptic neuron. Experiments were performed after $7-10 \mathrm{~d}$ in culture to allow for the development of excitatory synapses. NMDA receptors were blocked by adding $\mathrm{Mg}^{2+}(1 \mathrm{mM})$ and DL-AP5 (100 $\mu \mathrm{M})$ to a glycine-free solution. Under these conditions, EPSPs recorded from a membrane potential of $-70 \mathrm{mV}$ had a rapid rise and a decay consistent with selective activation of postsyn- aptic AMPA receptors. L-AP4 reversibly inhibited the EPSP amplitude by $46.5 \pm 18.5 \%(n=9)$. Similar effects were seen with NE $(n=4)$. L-AP4 had no effect on the membrane potential of either neuron or on the shape of the presynaptic action potential.

The top trace in Figure $5 A$ shows superimposed synaptic responses before and during perfusion with L-AP4. In sister cultures pretreated with $250 \mathrm{ng} / \mathrm{ml}$ PTX for $15-36 \mathrm{hr}$, neither L-AP4 nor NE had any significant effect on the EPSPs (Fig. $5 A$, middle trace; $B)$. AP4 $(30 \mu \mathrm{M})$ produced a $2.4 \pm 5.6 \%$ increase $(n-10)$, and NE caused a $3.0 \pm 2.0 \%$ decrease $(n=3)$. As shown in the bottom trace of Figure $5 \mathrm{~A}$, the postsynaptic AMPA receptor antagonist CNQX $(5 \mu \mathrm{M})$ produced a nearly complete block of the EPSP $(97 \pm 5.2 \% ; n=4)$, consistent with a glutamate-mediated EPSP. PTX treatment had no apparent effect on the leakage current or action potentials of the treated cells.

\section{Discussion}

Our results demonstrate that the AP4 receptor represents a G-protein-coupled glutamate receptor that is distinct from the metabotropic receptor. The action of L-AP4 on high-threshold calcium channels requires a G-protein based on the irreversible inhibition after intracellular dialysis with GTP- $\gamma-S$, and the lack of effect of L-AP4 in $\mathrm{Mg}^{2+}$-free solutions or after PTX pretreatment. Presynaptic inhibition of glutamate release from cultured olfactory bulb neurons by AP4 receptors also involved a PTXsensitive G-protein.

These properties are similar to the effects of G-protein-coupled receptors for other transmitters that modulate calcium channels. In fact, NE was also effective in reducing calcium currents in olfactory bulb neurons via the $\alpha_{2}$ receptor. The coupling of $\mathrm{G}$-protein receptors to calcium channels has been shown to involve an increasing variety of mechanisms. In cardiac and skeletal muscle, and in neurons, G-protein-coupled receptors modulate calcium channels by both direct and second messenger-mediated actions. Voltage-sensitive calcium channels can be activated directly by $\mathrm{G}_{s}$ or by $\mathrm{G}_{s}$-stimulated cAMP (Brown and Birnbaumer, 1988). Inhibition of calcium channels by G-proteins can also be either direct (Lipscombe et al., 1989; Toselli et al., 1989) or via second messenger-mediated actions (Trautwein et al., 1986; Rane et al., 1989). More than one G-protein may be involved, as both $\mathrm{G}_{s}$ (Yatani et al., 1987) and $\mathrm{G}_{o}$ (Hescheler et al., 1987; Toselli et al., 1989) have been implicated in modulation of calcium channel activity. Neurotrans- 
A

Control/30 $\mu \mathrm{M}$ L-AP4

Figure 5. EPSPs evoked from pairs of bulb neurons are reduced by L-AP4. $A$ : Top. Using simultaneous whole-cell recording from a pair of monosynaptically coupled bulb neurons, a $3 \mathrm{msec}$ depolarizing current pulse fired an action potential in the presynaptic cell evoking an EPSP in the postsynaptic neuron. The EPSPs were reduced by $46.5 \pm 18.5 \%$ in nine pairs $(30 \mu \mathrm{M}$ L-AP4) by a presynaptic mechanism. Bottom, In sister cultures pretreated with PTX (250 ng/ml, 15-36 hr), EPSPs evoked from pairs of bulb neurons were not reduced by $L-A P 4(n=10)$. Postsynaptic receptor antagonists, however, were still effective as $5 \mu \mathrm{M} C N Q X$ reduced the EPSP by $97 \pm 5.2 \%(n=4)$. Data from nine neurons are summarized in $B$.
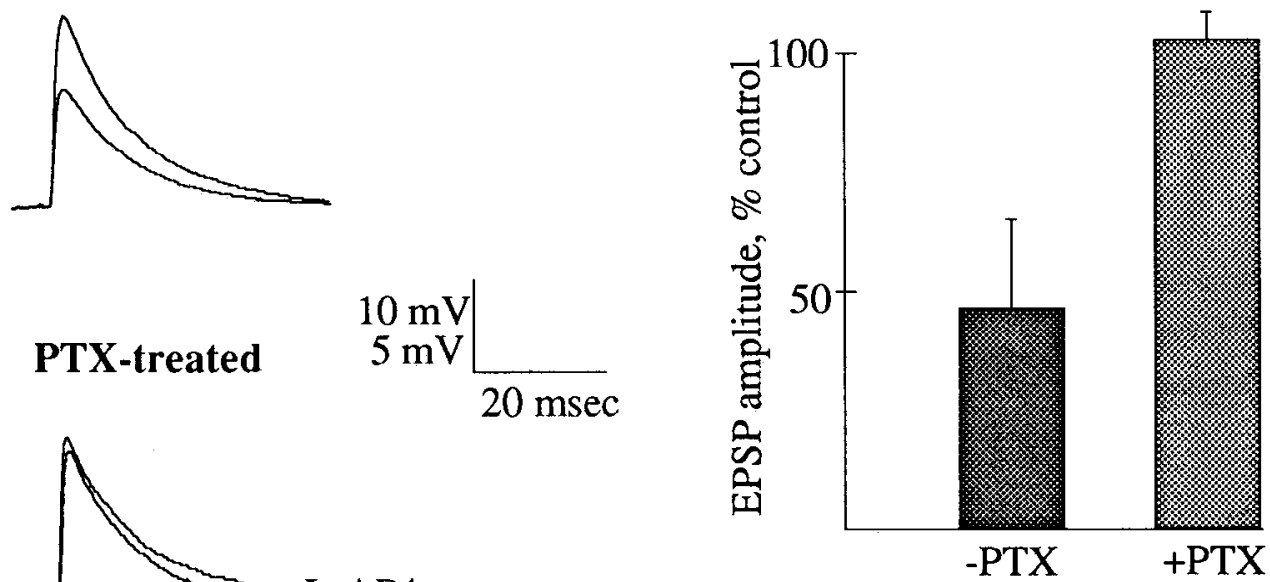

mitter-mediated calcium channel inhibition may also involve activation of protein kinase $\mathrm{C}$ (Rane et al., 1989) or release of calcium from intracellular stores (Kramer et al., 1991).

Our rcsults suggest that L-AP4 reduction of calcium currents does not involve protein phosphorylation or a diffusible second messenger such as calcium released from intracellular stores. Although calcium buffering with EGTA does not provide rapid control of transmembrane calcium influx, our experiments were done in barium (i.e., calcium-free) solutions. Likewise, L-AP4 was effective on repeated applications for periods of whole-cell dialysis of $>30$ min. This is inconsistent with a mechanism involving intracellular calcium stores, which should become depleted with repeated stimulation in calcium-free solutions (e.g., Murphy and Miller, 1988; Pfaffinger et al., 1988; Kramer et al., 1991).

PTX does not distinguish between $\mathrm{G}_{i}$ and $\mathrm{G}_{o}$; thus, the identity of the G-protein coupled to the AP4 receptor cannot be determined from our data. Although $\mathrm{G}_{o}$ is much more abundant in brain than $\mathrm{G}_{i}$, and $\mathrm{G}_{o}$ appears to couple inhibitory receptors to calcium channels in dorsal root ganglion ncurons (Ewald et al., 1989) and NG108 cells (Hescheler et al., 1987; McFadzean et al., 1989), reconstitution experiments have not demonstrated clear specificity of $\alpha$-subunits for every receptor (e.g., Ewald et al., 1989). Whether the presynaptic AP4 receptor is the same as the L-AP4-activated receptor involved in G-protein coupling to phosphodiesterase in retinal depolarizing bipolar cells (Nawy and Jahr, 1990) is also unclear. The G-protein involved in the bipolar cell has not yet been characterized. However, the retinal receptor could conceivably differ from the presynaptic AP4 receptor only in its coupling mechanism.

\section{Comparison with the metabotropic glutamate receptor}

Several observations suggest that the effects of L-AP4 do not result from activation of the metabotropic glutamate receptor. First, L-AP4 does not stimulate inositol phospholipid turnover in several different mammalian preparations (sec Schocpp et al., 1990) or in oocytes injected with whole-brain mRNA or the cloned metabotropic receptor transcript (Sugiyama et al., 1987; Sugiyama et al., 1989; Houamed et al., 1991). Second, staurosporine did not block the response to L-AP4 in our experiments, suggesting that activation of protein kinase $C$ was not required. Third, $\mathrm{IP}_{3}$-mediated calcium release by quisqualate is depleted after repeated applications in calcium-free solutions (Murphy and Miller, 1988). Thus, the L-AP4 response, if due to metabotropic receptor stimulation, would be expected to disappear in barium solutions. It did not. However, in addition to L-glutamate, ibotenate and quisqualate, which both activate the metabotropic receptor, also inhibited barium currents in our experiments. Thus, the AP4 receptor may bind many of the same ligands as the metabotropic receptor. By contrast, L-AP4 has been reported to antagonize $\mathrm{IP}_{3}$ turnover in adult rat brain slices (Nicoletti et al., 1986; Schoepp and Johnson, 1988), but this was not seen in hippocampal slices from newborn animals (Nicoletti et al., 1986) or in measurements of quisqualate-evoked calcium transients in isolated hippocampal neurons (Murphy and Miller, 1988). Part of this discrepancy has been attributed to developmental changes in the efficacy of mctabotropic receptor antagonists (Schoepp et al., 1990). However, the most potent metabotropic receptor antagonist, 2-amino-3-phosphonoprioprionic acid (AP3; Schoepp and Johnson, 1989), is ineffective in mimicking the presynaptic action of L-AP4 in hippocampal slices (Koerner and Cotman, 1981).

Our results also differ in several respects from the quisqualateinduced inhibition of calcium currents in cultured CAl hippocampal neurons (Lester and Jahr, 1990). The inhibition by quisqualate required the presence of intra- or extracellular calcium, was enhanced in GTP- $\gamma$-S compared to GTP, and was not mimicked by L-AP4. The lack of L-AP4 action may be explained by the relative insensitivity of the Schaffer collateralCA1 pathway to the presynaptic effects of L-AP4 (Koerner and Cotman, 1982). Although the quisqualate-induced inhibition required calcium, dialysis with kinase inhibitors, tight buffering with BAPTA, or dialysis with $\mathrm{IP}_{3}$ did not block the effect of quisqualate (Lester and Jahr, 1990). Therefore, if this response 
was via activation of the metabotropic receptor, it is unlikely to result from phospholipase $\mathrm{C}$ activation. We have observed in preliminary experiments that the selective metabotropic receptor agonist trans-1-amino-cyclopentyl-1,3-dicarboxylic acid (trans-ACPD; Palmer et al., 1989), can inhibit barium currents on cultured hippocampal neurons with intracellular calcium buffered to $10 \mathrm{~nm}$ (Sahara and Westbrook, 1991). Thus, it may be that the metabotropic receptor activates several different transduction pathways. Consistent with this possibility, trans-ACPD has been reported to inhibit potassium conductances in hippocampal neurons independent of changes in intracellular calcium (Charpak et al., 1990). This may be analogous to the action of substance $\mathrm{P}$ and leutinizing hormone-releasing hormone, which stimulate $\mathrm{IP}_{3}$, but independently inhibit M-current on frog sympathetic neurons (Pfaffinger et al., 1988).

\section{The mechanism of presynaptic inhibition}

Although inhibition of calcium currents has long been an attractive hypothesis for the mechanism of presynaptic inhibition by neurotransmitters, definitive evidence has been difficult to obtain. The extrapolation of results obtained on somatic calcium currents to the presynaptic terminal have been further complicated by the discovery of calcium channel subtypes (Fox et al., 1987). In particular, the contributions of different subtypes of high-threshold calcium channels to transmitter release may differ between pathways. Only a few studies have made a direct comparison of neurotransmitter effects on calcium currents and transmitter release. In dorsal root ganglion neurons, both GABA and NE inhibit the high-threshold calcium current (Dunlap et al., 1987), and also reduce potassium-evoked substance $\mathrm{P}$ release, an effect mimicked by dihydropyridines (Perney et al., 1986; Rane et al., 1987). In sympathetic neurons, $\mathrm{N}$-type currents control transmitter release (Hirning et al., 1988), and adrenergic receptor stimulation inhibits both $\mathrm{N}$-currents and synaptic release (Lipscombe et al., 1989). A similar correlation has been found for the Al adenosine receptor on cultured hippocampal neurons (Scholz and Miller, 1991). Although dihydropyridines have been reported to be ineffective in blocking electrically induced substance P release (Rane et al., 1987) and in blocking synaptic transmission in slices of olfactory cortex (Kuan and Schofield, 1986), a substantial component of the highthreshold calcium current in cultured olfactory bulb neurons was blocked by nifedipine. Regardless of the calcium channel subtype, our results suggest that similar G-proteins are involved in AP4 rcceptor-mediated inhibition of both high-threshold calcium currents and excitatory synaptic transmission. This makes it plausible that a direct effect of the activated G-protein on high-threshold calcium channels underlies presynaptic inhibition.

\section{Autoreceptor function at excitatory synapses}

Despite the widespread existence of presynaptic autoreceptors, how they affect ongoing synaptic transmission is not well understood. Two scenarios can be imagined for the L-AP4 receptor. First, a low level of glutamate present in the synaptic cleft could lower transmitter release due to the potent inhibition of transmitter release by $<1 \mu \mathrm{M}$ glutamate (Forsythe and Clements, 1990), a concentration that is only minimally effective in activating glutamate channels. This might be increased during periods of intense synaptic activity or under "excitotoxic" conditions. As a second possibility, AP4 reccptors could be activated during high-frequency stimulation as the concentration of glu- tamate in the cleft may peak above $1 \mathrm{~mm}$ and take more than $10 \mathrm{msec}$ to return to concentrations below $1 \mu \mathrm{M}$ (Clements et al., 1991). Thus, a membrane-delimited G-protein action might be advantageous in eliminating the long latency that accompanies the activation of a diffusible second messenger (e.g., Horn and Marty, 1988; Furuya et al., 1989). Transmitter release during a burst of action potentials lasting 50-100 msec could be altered via the autoreceptor under these conditions.

The marked regional differences in the potency of L-AP4 as a synaptic depressant could reflect differences in the affinity or numbers of presynaptic AP4 receptors or in the number of available G-proteins or calcium channels. The high L-AP4 sensitivity of the lateral perforant path input to the dentate gyrus $\left(\mathrm{IC}_{50}=2.5 \mu \mathrm{M}\right.$; Koerner and Cotman, 1981) contrasts with the Schaffer collateral-CA1 pathway $\left(\mathrm{IC}_{50}>1 \mathrm{mM}\right)$. Functionally, this might serve to reduce excitatory input to the hippocampus, perhaps contributing to a role of the dentate gyrus as a "gate" for synaptic activity entering the hippocampus. In addition to an action of L-AP4 in the lateral olfactory tract, the existence of dendrodendritic synapses in the olfactory bulb could provide another presynaptic site for modulation by glutamate (or adrenergic) autoreceptors. Although there is no direct evidence for this at present, similar mechanisms have been observed following dendritic release of dopamine in the substantia nigra (Cheramy et al., 1981).

\section{References}

Anson J, Collins GGS (1987) Possible presynaptic actions of 2-amino4-phosphonobutyrate in rat olfactory cortex. $\mathrm{Br} \mathrm{J}$ Pharmacol 91:753761.

Baskys A, Malenka RC (1991) trans-ACPD depresses synaptic transmission in the hippocampus. Eur J Pharmacol 193:131-132.

Bean BP (1989) Neurotransmitter inhibition of neuronal calcium currents by changes in channel voltage dependence. Nature 340:153156.

Brown AM, Birnbaumer L (1988) Direct $G$ protein gating of ion channels. Am J Physiol 254:H401-H410.

Cheramy A, Leviel V, Glowinski J (1981) Dendritic release of dopamine in the substantia nigra. Nature 289:537-542.

Chernevskaya NI, Obukhov AG, Krishtal OA (1991) NMDA receptor agonists selectively block $\mathrm{N}$-type calcium channels in hippocampal neurons. Nature 349:418-420.

Charpak S, Gähwiler BH, Do KQ, Knöpfel T (1990) Potassium conductances in hippocampal neurons blocked by excitatory amino-acid transmitters. Nature 347:765-767.

Clements JD, Lester RAJ, Jahr CE, Westbrook GL (1991) The time course of glutamate in the synaptic cleft. Soc Neurosci Abstr 17:256.

Collingridge GL, Lester RAJ (1989) Excitatory amino acid receptors in the vertebrate central nervous system. Pharmacol Rev 40:143-210.

Cotman CW, Monaghan DT, Ottersen OP, Storm-Mathiscn J (1987) Anatomical organization of excitatory amino acid receptors and their pathways. Trends Neurosci 7:273-280.

Davies J, Watkins JC (1982) Action of $\mathrm{D}$ and $\mathrm{L}$ forms of 2-amino-5phosphonovalerate and 2-amino-4-phosphonobutyrate in the cat spinal cord. Brain Res 235:378-386.

Dunlap K, Holz GG, Rane SG (1987) G proteins as regulators of ion channel function. Trends Neurosci 10:241-244.

Elmslie KS, Zhou W, Jones SW (1990) LHRH and GTP-gamma-S modify calcium current activation in bullfrog sympathetic neurons. Neuron 5:75-80.

Ewald DA, Pang I-H, Sternweis PC, Miller RJ (1989) Differential G protein-mediated coupling of neurotransmitter receptors to $\mathrm{Ca}^{2+}$ channels in rat dorsal root ganglion neurons in vitro. Neuron 2:11851193.

Forsythe ID, Clements JD (1990) Presynaptic glutamate receptors depress excitatory monosynaptic transmission between mouse hippocampal neurones. J Physiol (Lond) 429:1-16.

Forsythe ID, Westbrook GL (1988) Slow excitatory postsynaptic cur- 
rents mediated by $N$-methyl-D-aspartate receptors on cultured mouse central neurons. J Physiol (Lond) 396:515-533.

Fox AP, Nowycky MC, Tsien RW (1987) Kinetic and pharmacological properties distinguishing three types of calcium currents in chick sensory neurons. J Physiol (Lond) 394:149-172.

Furuya S, Ohmori H, Shigemoto T, Sugiyama H (1989) Intracellular calcium mobilization triggered by a glutamate receptor in rat cultured hippocampal cells. J Physiol (Lond) 414:539-548.

Gilman AG (1987) G proteins, transducers of receptor-generated signals. Annu Rev Biochem 56:615-649.

Harris EW, Cotman CW (1983) Effects of acidic amino acid antagonists on paired-pulse potentiation at the lateral perforant path. Exp Brain Res 52:455-460.

Hescheler J, Rosenthal W, Trautwein W, Schultz G (1987) The GTPbinding protein, $\mathrm{G}_{o}$, regulates neuronal calcium channels. Nature 325 : 445-447.

Hirning LD, Fox AP, McCleskey EW, Olivera BM, Thayer SA, Miller $\mathrm{RJ}$, Tsien RW (1988) Dominant role of $\mathrm{N}$-type $\mathrm{Ca}^{2+}$ channels in evoked release of norepinephrine from sympathetic neurons. Science 239:57-61.

Holz IV GG, Kream RM, Spiegel $\Lambda$, Dunlap K (1989) G proteins couple $\alpha$-adrenergic and $\mathrm{GABA}_{\mathrm{b}}$ receptors to inhibition of peptide secretion from peripheral sensory neurons. J Neurosci 9:657-666.

Horn R, Marty A (1988) Muscarinic activation of ionic currents measured by a new whole-cell recording method. J Gen Physiol 92:145159.

Houamed KM, Kuijper JL, Gilber TL, Haldeman BA, O'Hara PJ, Mulvihill ER, Almers W, Hagen FS (1991) Cloning, expression, and gene structure of a $G$ protein-coupled glutamate receptor from rat brain. Science 252:1318-1321.

Koerner JF, Cotman CW (1981) L-2-Amino-phosphonobutyric acid selectively inhibits perforant path synapses from lateral entorhinal cortex. Brain Res 216:192-198.

Koerner JF, Cotman CW (1982) Response of Schaffer collateral-CAl pyramidal cell synapses of the hippocampus to analogues of acidic amino acids. Brain Res 251:105-115.

Kramer RH, Kaczmarek LK, Levitan ES (1991) Neuropeptide inhibition of voltage-gated calcium channels medicated by mobilization of intracellular calcium. Neuron 6:557-563.

Kuan YF, Scholfield CN (1986) Ca-channel blockers and the electrophysiology of synaptic transmission of the guinea-pig olfactory cortex. Eur J Pharmacol 130:273-278.

Lester RAJ, Jahr CE (1990) Quisqualate receptor-mediated depression of calcium currents in hippocampal neurons. Neuron 4:741-749.

Lester RAJ, Clements JD, Westbrook GL, Jahr CE (1990) Channel kinetics determine the time course of NMDA receptor mediated synaptic currents. Nature 346:565-567.

Lipscombe D, Kongsamut S, Tsien RW (1989) Alpha-adrenergic inhibition of sympathetic ncurotransmitter release mediated by modulation of N-type calcium-channel gating. Nature 340:639-642.

Masu M, Tanabe Y, Tsuchida K, Shigemoto R, Nakanishi S (1991) Sequence and expression of a metabotropic glutamate receptor. Nature 349:760-765.

Mayer ML, Westbrook GL (1987) The physiology of excitatory amino acids in the vertebrate central nervous system. Prog Neurobiol 28 : 197-276.

McFadzean I, Mullaney I, Brown DA, Milligan G (1989) Antibodies to the GTP binding protein, $\mathbf{G}_{o}$, antagonize noradrenaline-induced calcium current inhibition in NG108-15 hybrid cells. Neuron 3:177182.

Miller RF, Slaughter MM (1986) Excitatory amino acid receptors of the retina: diversity of subtypes and conductance mechanisms. Trends Neurosci 9:211-218.

Murphy SN, Miller RJ (1988) A glutamate receptor regulates $\mathrm{Ca}^{2+}$ mobilization in hippocampal neurons. Proc Natl Acad Sci USA 85: $8737-8741$.

Murphy SN, Miller RJ (1989) Two distinct quisqualate receptors regulate $\mathrm{Ca}^{2+}$ homeostasis in hippocampal neurons in vitro. Mol Pharmacol 35:671-680.

Nawy S, Jahr CE (1990) Suppression by glutamate of cGMP-activated conductance in retinal bipolar cells. Nature 346:269-271.
Nicoletti F, Iadarola MJ, Wroblewski JT, Costa E (1986) Excitatory amino acid recognition sites coupled with inositol phospholipid metabolism, developmental changes and interaction with alphal-adrenoceptors. Proc Natl Acad Sci USA 83:1931-1935.

Nicoletti F, Wroblewski JT, Fadda E, Costa E (1988) Pertussis toxin inhibits signal transduction at a specific metabotropic glutamate receptor in primary cultures of cerebellar granule cells. Neuropharmacology 27:551-556.

Palmer E, Monaghan DT, Cotman CW (1989) trans-ACPD, a selective agonist of the phosphoinositide-coupled excitatory amino acid rcceptor. Eur J Pharmacol 166:585-587.

Perney TM, Hirning LD, Leeman SE, Miller RJ (1986) Multiple calcium channels mediate neurotransmitter release from peripheral neurons. Proc Natl Acad Sci USA 83:6656-6659.

Pfaffinger PJ, Leibowitz MD, Subers EM, Nathanson NM, Almers W, Hille B (1988) Agonists that suppress M-current elicit phosphoinositide turnover and $\mathrm{Ca}^{2+}$ transients, but these events do not explain M-current suppression. Neuron 1:477-484.

Rane SG, Holz IV GG, Dunlap K (1987) Dihydropyridine inhibition of neuronal calcium current and substance P release. Pfluegers Arch 409:361-366

Rane SG, Walsh MP, McDonald JR, Dunlap K (1989) Specific inhibitors of protein kinase $C$ block transmitter-induced modulation of sensory neuron calcium current. Neuron 3:239-245.

Regan LJ, Sah DW, Bean BP (1991) $\mathrm{Ca}^{2+}$ channels in rat central and peripheral neurons: high-threshold current resistant to dihydropyridine blockers and omega-conotoxin. Neuron 6:269-280.

Ross EM (1989) Signal sorting and amplification through $G$ proteincoupled receptors. Neuron 3:141-152.

Rüegg UT, Burgess GM (1989) Staurosporine, K-252 and UCN-01: potent but nonspecific inhibitors of protein kinases. Trends Pharmacol Sci 10:218-220.

Sahara Y, Westbrook GL (1991) trans-ACPD blocks high threshold calcium currents on cultured hippocampal neurons. Soc Neurosci Abstr 17:1168

Schoepp DD, Johnson BG (1988) Excitatory amino acid agonist-antagonist interactions at 2-amino-4-phosphonobutyric acid-sensitive quisqualate receptors coupled to phosphoinositide hydrolysis in slices of rat hippocampus. J Neurochem 50:1605-1613.

Schoepp DD, Johnson BG (1989) Inhibition of excitatory amino acidstimulated phosphoinositide hydrolysis in the neonatal rat hippocampus by 2-amino-3-phosphonopropionate. J Neurochem 53:1865-1870.

Schoepp D, Bockaert J, Sladeczek F (1990) Pharmacological and functional characteristics of metabotropic excitatory amino acid receptors. Trends Pharmacol Sci 11:508-515.

Scholz KP, Miller RJ (1991) Analysis of adenosine actions on $\mathrm{Ca}^{2+}$ currents and synaptic transmission in cultured rat hippocampal pyramidal neurones. J Physiol (Lond) 435:373-393.

Sladeczek F, Recasens M, Bockaert J (1988) A new mechanism for glutamate receptor action: phosphoinositide hydrolysis. Trends Neurosci 11:545-549.

Sugiyama H, Ito I, Hirono C (1987) A new type of glutamate receptor linked to inositol phospholipid metabolism. Nature 325:531-533.

Sugiyama H, Ito I, Watanabe M (1989) Glutamate receptor subtypes may be classified into two major categories: a study on Xenopus oocytes injected with rat brain mRNA. Neuron 3:129-132.

Surprenant A (1989) The neurotransmitter noradrenaline and its receptors. Semin Neurosci 1:125-136.

Toselli M, Lang J, Costa T, Lux HD (1989) Direct modulation of voltage-dependent calcium channels by muscarinic activation of a pertussis toxin-sensitive G-protein in hippocampal neurons. Pfluegers Arch 415:255-261.

Trautwein W, Kameyama M, Hescheler J, Hofmann F (1986) Cardiac calcium channels and their transmitter modulation. Fortschr Zool 33: 163-182.

Trombley PQ, Wcstbrook GL (1990) Excitatory synaptic transmission in primary cultures of rat olfactory bulb. J Neurophysiol 64:598-606.

Yatani A, Codina J, Imoto Y, Reeves JP, Birnbaumer L, Brown AM (1987) A G protein directly regulates mammalian cardiac calcium channels. Science 238:1288-1292. 